\title{
Health aspects of sanitation among Eastern Cape (EC) rural communities, South Africa
}

\author{
N Phaswana-Mafuya, Ph D \\ Chief Research Manager, Human Sciences Resources Council
}

\section{Keywords:}

Sanitation, health, rural communities, Eastern Cape, South Africa

\section{Correspondence address:}

Dr Nancy Phaswana-Mafuya

Social Aspects of HIV/AIDS and Health

Human Sciences Research Council

$10^{\text {th }}$ floor, Pleinpark Building

Cape Town, 8000

Tel: (021) 466-7914

Fax: (021) 461-2696,

Email: nphaswanamafuya@hsrc.ac.za

\section{Abstract: Curationis 29(2): 41-47}

A descriptive study was conducted to determine the health aspects of sanitation among rural communities of the EC. A purposive sample of 145 villagers was drawn from 14 villages selected through systematic random sampling. Of these, 71 were male and 74 were female. The 145 participants were divided into 14 groups ( $M=10$ participants) by community and randomly assigned to 14 community-based trained facilitators. Each facilitator administered Dunker's (2001) KAP tool for hygiene to the assigned group. The responses from all the groups were collated and analysed. Communities' health was generally not considered good (78.6\%) because of limited clean water, lack of money to treat water and unhealthy food. The prevalence of diseases in the last 6 months, included: skin diseases, worms, eye infections, diarrhoea. bilharzias and malaria: the perceived causes of diseases were mainly related to poor sanitation and the suggested disease prevention methods were sanitation improvement related. Institutional capacity was generally lacking as more than $50 \%$ of the communities did not have sanitation committees and environmental health officers (98.3\%); health (64.3\%) and water (57.1\%) committees. The results have implications for policy-makers, programme planners, academics and practitioners in the field of water and sanitation in terms of policy and programme formulation, curriculum development, and service delivery.

\section{Introduction}

Sanitation facilities are not adequate in many countries including South Africa (Alcock, 1999: 5 and Johnstone \& Porras, 2003: 108). Approximately 3 billion people in Africa lack access to adequate sanitation (DWAF, 2002b: 1; Stephen, 2003: 48 \& Tladi, Baloyi, Schreiber-Kaya, Mathekgana, Mangold, de Klerk \& Winde, 2002: 17). In 1994 it was estimated that approximately 21 million people in South Africa lacked access to adequate sanitation services (DWAF, 1994: 9). This figure went down to 18 million in 2001 (DWAF, 2001: 9). However, despite investments in sanitation programmes, the population with access to safe sanitation remains low (Stephen, 2003: 50 ), especially in rural areas. Poor sanitation affects the quality of life, and in many cases, can result in deaths and diseases which place an additional financial and health burden on poor families (Tumwine, Thomson, KatuiKatua, Mujwanhuzi, Johnstone \& Porras, 2003: 107). For example, an estimated 10 000 people die every day from water and sanitation related diseases and thousands more suffer from a range of debilitating illnesses (Tladi et.al. 2002:17). Hemson (2003: 3 \& 2004: 14) reports that inadequate sanitation has an acute effect on child mortality rates in South Africa i.e. child mortality is twice as high for those households which do not piped water and four times high for those households which do not have flush toilets. The impact of inadequate sanitation on the health of the community and others downstream, is extremely serious as witnessed by the 1.5 million cases annually of diarrhoea in children under the age of 5 and the cholera outbreaks (DWAF, 1996: 40). Other health problems associated with 
inadequate sanitation are typhoid, bilharzias, malaria, cholera, worms, eye infections, skin diseases and increased risk for bacteria, infections and disease for people with reduced immune systems due to HIV/AIDS (DWAF, 1996: 39; DWAF, 2004: 19); Tladi et. al. 2002: 17). The current study explores the health aspects of sanitation, such as health status of communities; the prevalence, incidence, causes, prevention and treatment of diseases as well as available institutional capacity to deal with the diseases; among 14 rural communities of the Eastern Cape. Rural communities were chosen because they generally have little or no basic services (water, sewerage, communications, electricity) compared to the large towns, even when they are located adjacent to the large towns (DWAF, 2002b: 1; Tladi et.al. 2002: 17 and DWAF, 1996: 8). It is hoped that the information derived from this study not only sheds some light on the health status of rural communities but also provide critical information upon which sanitation policy and programming efforts can be based.

\section{Methods \\ Design and setting}

A descriptive survey was conducted in the Eastern Cape Province which is situated along the southeast coast of South Africa and covers an area of 170 $000 \mathrm{~km}^{2}$, representing about $14 \%$ of the country's landmass. It has a population size of approximately seven million, representing $16 \%$ (third largest) of the South African population. The nonurban population amounts to nearly 4100 000 , and dense concentrations of rural and peri-urban settlements occur in other districts and areas. The Eastern Cape is one of the provinces with the highest levels of poverty, underdeveloped infrastructure and unemployment (Eastern Cape Department of Social Development, 2004: 14). The province consists of seven district municipalities, namely: Oliver Tambo (Kei), Amatole, Western, Chris Hani (Stormberg), Ukhahlamba (Drakensburg), Alfred Nzo and East Griqualand Kei (Wild Coasst). One district municipality was identified for the study, namely Amatole District Municipality (ADM). The ADM is divided into 8 local municipalities which are Nxuma (Adelaide), Mnquma (Butterworth), Nkonkobe (Fort Beaufort), Mbashe (Idutywa), Great Kei (Komga), Ngqushwa (Peddie), Amahlathi
(Stutterheim) and Buffalo City (East London and King Williams Town). The study was confined to the Ngqushwa local municipality due financial and time constraints. The Ngqushwa local municipality has 14 wards with a total population of 93997 people, made up of 20757 households. The population is evenly spread across the 14 wards. The average number of people per ward is 6 714 (1 483) households. The average household size is $4.5 \%$ persons. The total number of villages across the 14 wards is 112 .

\section{Sample and procedure}

Approval for the research was requested from and granted by the Ngqushwa Municipality. A list of 112 villages spread across the 14 wards of the Ngqushwa local municipality was provided. Systematic random sampling was used to select 1 village from a list of the villages in each ward. The 14 villages identified for the study included: Bongweni, Dubu, Gcinisa North, Gcinisa South, Lower Qeto, Luxolweni, Machibi, Mpeko, Mtati, Nobumba, Ntloko, Pedie extension, Qawukeni, and Woolridge. In each village, the researcher requested the local authorities to provide a list of 15 villagers who were knowledgeable about their community sanitation issues. Subsequently, the person chosen by the local authorities to assist the researcher with the research process in each village provided the researcher with a list of 15 villagers including grassroots women, nurses, teachers, the youth, village health workers, pastors, social workers, traditional leaders, traditional healers, representatives from various community structures, and pressure groups. The list contained the name of the participant, telephone number, fax number, office number and email address (where applicable). The total number of villagers across the 14 villages amounted to 210 ( 15 villagers per village). These villagers were considered a purposive sample for the study. From a purposive sample of 210 villagers, 145 who constituted $69 \%$ of the total sample consented to participate in the study after being advised of their: a) their status as volunteers, (b) their right to refuse to answer any question, (c) the legal liabilities of their participation, (d) confidentiality, and (e) the limitations of anonymity due to the nature of the study. The researcher ensured that: the group was sufficiently representative; there was an agreement on goals; and group members understood the constraints that applied. The distribution of villagers per village was as follows: 10 for Bongweni, Dubu, Gcinisa North, Gcinisa South, Lower Qeto, Luxolweni, Machibi, Mpeko and Mtati respectively and 11 for Nobumba, Ntloko, Peddie extension, Qawukeni, and Woolridge respectively. Only $31 \%$ did not participate in the study, as they were not available at the time when the study was conducted. Of the 145 villagers, $49 \%(\mathrm{~N}=71)$ were males and $51 \%(\mathrm{~N}=74)$ were females.

\section{Instrument}

Dunker's (2001: 1-11) KAP tool for hygiene in rural areas was adopted for the study. Prior to administering the tool, a pilot study with 10 villagers was undertaken in one of the non-sampled villages at Ngqushwa District. Thereafter, the wording of the original tool was reviewed and modified accordingly. Ambiguity of meaning was eliminated; clarity, comprehensibility and simplicity of items were ensured. The tool was adjusted in order to accommodate the cultural sensitivity of the participants.

\section{Data collection method}

Group interviews were used to collect data from the 14 randomly selected community groups. Information was collected from each small group in a single session. The group interviews involved an interactive procedure where the researcher collected the data in a dialogue with informants. This method of data collection was chosen because of its suitability to the type of data being collected and cost-effectiveness.

\section{The process}

Fourteen (14) trained community-based facilitators served as data collectors for the study. Their main function as facilitators was to guide the group through the interviewing process. The purpose was to achieve an end result which is one that the group members have reached by themselves and which reflects their real views. For this to happen, each member of the group was made to feel able to contribute her/her views safely. Group members were also encouraged to listen to one another (or a genuine group consensus cannot emerge), and to communicate cooperatively rather than competitively. Facilitators helped each group to generate its own information while it takes responsibility for its own effectiveness in doing so. Each facilitator reminded group members that they were 


\begin{tabular}{|c|c|}
\hline Perception of health & $\mathbf{N}(\%)$ \\
\hline Community's health is considered good & $3(21.4)$ \\
\hline Community's health is not good, because: & $11(78.6)$ \\
\hline Clean water is not enough & $1(7.1)$ \\
\hline No money for treatment & $8(57.1)$ \\
\hline Unhealthy food & $2(14.3)$ \\
\hline Causes of poor community health: & $\mathbf{N}(\%)$ \\
\hline Unemployment and poverty & $5(35.7)$ \\
\hline Unavailability of health workers & $1(7.1)$ \\
\hline Lack of sanitation resources & $3(21.4)$ \\
\hline Insufficient knowledge & $2(14.3)$ \\
\hline Lack of health facilities i.e. clinic & $3(21.4)$ \\
\hline Flies & $\mathbf{N}(\%)$ \\
\hline The community thinks flies are a problem & $13(92.9)$ \\
\hline Reasons flies are a problem: & $\mathbf{N}(\%)$ \\
\hline They spread diseases & $3(21.4)$ \\
\hline They are germ carriers & $10(71.4)$ \\
\hline They cause diseases & $1(7.1)$ \\
\hline They are filthy & $1(7.1)$ \\
\hline Flies are attracted by & $\mathbf{N}(\%)$ \\
\hline Dirty dishes & $4(28.6)$ \\
\hline Dirty water & $7(50.0)$ \\
\hline Dirty surroundings & $3(21.4)$ \\
\hline What does community do to prevent flies? & $\mathbf{N}(\%)$ \\
\hline Use disinfectants & $3(21.4)$ \\
\hline Use fly catchers & $3(21.4)$ \\
\hline Clean surroundings & $3(21.4)$ \\
\hline Beat them with hands & $2(14.3)$ \\
\hline Doom them & $3(21.4)$ \\
\hline Hygiene Education & $\mathbf{N}(\%)$ \\
\hline Is hygiene education necessary? & $14(100)$ \\
\hline Community aware of: & $\mathbf{N}(\%)$ \\
\hline Re-hydration mixtures for diarrhoea & $9(64.3)$ \\
\hline Medicines and bandages for treating burns & $10(71.4)$ \\
\hline Antiseptics and bandages for treating cuts, bites, etc. & $10(71.4)$ \\
\hline Insect repellent for mosquitoes, flies, fleas, etc. & $10(71.4)$ \\
\hline Nutrition & $\mathbf{N}(\%)$ \\
\hline Does the community have vegetable gardens & \\
\hline Yes & $9(64.3)$ \\
\hline No & $6(42.9)$ \\
\hline If not, where do they get vegetables? & \\
\hline Market & $8(57.1)$ \\
\hline No response & $6(42.9)$ \\
\hline How often does the community eat vegetables? & \\
\hline Daily & $3(21.4)$ \\
\hline Twice a week & $4(28.6)$ \\
\hline Once a week & $5(35.7)$ \\
\hline When they are ready & $1(7.1)$ \\
\hline During festive seasons & $1(7.1)$ \\
\hline
\end{tabular}

using a collaborative process. Their goal was to understand and communicate the view or views of the community as a whole. The facilitators then administered the questionnaire to the group members. Group members answered questions individually. Summaries of the responses to the questions were then written up and used as the basis for discussion. Group members used their individual responses as a means of knowing if there is close to a group consensus on some items. They decided on what should finally be written as a group response and they agreed on the wording with which the responses must be communicated. When the final wording was agreed on, it was then transferred to an appropriate space on the questionnaire without neither changing the words nor leaving out material. The group interviews were conducted in the indigenous language (Xhosa). The average number of members per group was 10. Each group interview lasted for about two hours.

\section{Data Analysis}

The 14 facilitators submitted completed group interview questionnaires for their respective groups to the researcher. Each group questionnaire was numbered to ensure that data capturers were able to go back to it should there be some queries. The researcher created the variables for quantitative data on SPSS version 11.0. Responses were then entered on SPSS. The data was then cleaned and analysed as reflected in the results section. Qualitative responses to open ended questions were quantified using thematic content analysis.

\section{Results \\ Health}

Communities' health was generally not considered good $(78.6 \%)$ because of limited clean water, lack of money to treat water and unhealthy food. The majority of the communities $(64.3 \%)$ did not have vegetable gardens and therefore did not eat vegetables daily $(78.5 \%)$. Flies were perceived as a problem in the communities and participants indicated that they were attracted by dirty dishes, dirty water and dirty surroundings. Various methods were evenly used to prevent flies, namely disinfectants, fly catchers, maintaining clean surroundings, dooming them and beating them with hands. All participants felt that hygiene education was necessary within their communities even if more than $60 \%$ 


\begin{tabular}{|c|c|c|c|c|}
\hline \multicolumn{3}{|c|}{$\begin{array}{l}\text { Any member of community suffered from the following } \\
\text { diseases in the last } 6 \text { months }\end{array}$} & \multicolumn{2}{|l|}{$\mathrm{N}(\%)$} \\
\hline \multicolumn{3}{|c|}{ Diarrhoea } & \multicolumn{2}{|l|}{$4(28.6)$} \\
\hline \multicolumn{3}{|l|}{ Worms } & \multicolumn{2}{|l|}{$9(64.3)$} \\
\hline \multicolumn{3}{|l|}{ Bilharzias } & \multicolumn{2}{|l|}{$3(21.4)$} \\
\hline \multicolumn{3}{|l|}{ Malaria } & \multicolumn{2}{|l|}{$1(7.1)$} \\
\hline \multicolumn{3}{|l|}{ Eye infections } & \multicolumn{2}{|l|}{$6(42.9)$} \\
\hline \multicolumn{3}{|l|}{ Skin diseases } & \multicolumn{2}{|l|}{$13(92.9)$} \\
\hline Disease suffered in the last 6 months & $\begin{array}{l}\text { None } \\
\text { N }(\%)\end{array}$ & $\begin{array}{l}1-2 \\
\mathbf{N}(\%) \\
\end{array}$ & $\begin{array}{l}3-4 \\
N(\%)\end{array}$ & $\begin{array}{l}5+ \\
N(\%) \\
\end{array}$ \\
\hline Diarrhoea & $10(71.4)$ & $1(7.1)$ & $2(14.3)$ & $1(7.1)$ \\
\hline Worms & $5(35.7)$ & $2(14.3)$ & $1(7.1)$ & $6(42.9)$ \\
\hline Bilharzias & $10(71.4)$ & $1(7.1)$ & $1(7.1)$ & $2(14.3)$ \\
\hline Malaria & $12(85.7)$ & $2(14.3)$ & $0(0.0)$ & $0(0.0)$ \\
\hline Eye Infections & $7(50.0)$ & $2(14.3)$ & $2(14.3)$ & $6(42.9)$ \\
\hline Skin Diseases & $1(7.1)$ & $1(7.1)$ & $0(0.0)$ & $12(85.7)$ \\
\hline
\end{tabular}

of the groups indicated that their communities were generally aware of rehydration mixtures for diarrhoea,

medicines and bandages for treating burns, antiseptics and bandages for treating cuts, bites, etc. and insect

\section{Table 3: Causes of Diseases (Positive Responses)}

\begin{tabular}{|c|c|c|}
\hline Diseases & Causes & $\mathbf{N}(\%)$ \\
\hline Diarrhoea & $\begin{array}{l}\text { Dirty water } \\
\text { Unpurified water from dams and rivers } \\
\text { Unhealthy diet }\end{array}$ & $\begin{array}{l}8(57.1) \\
4(28.6) \\
2(14.3)\end{array}$ \\
\hline Worms & $\begin{array}{l}\text { Dirty water } \\
\text { Unhealthy diet } \\
\text { Don't know }\end{array}$ & $\begin{array}{l}2(14.3) \\
10(71.4) \\
2(14.3)\end{array}$ \\
\hline Bilharzias & $\begin{array}{l}\text { Swimming in stagnant water } \\
\text { Dirty water } \\
\text { Don't know }\end{array}$ & $\begin{array}{l}3(21.4) \\
8(57.1) \\
2(14.3)\end{array}$ \\
\hline Malaria & $\begin{array}{l}\text { Mosquitoes resulting from dirty water } \\
\text { Dirty water }\end{array}$ & $\begin{array}{l}13(92.9) \\
1(7.1)\end{array}$ \\
\hline Eye Infections & $\begin{array}{l}\text { Touching eyes without washing hands } \\
\text { Unhealthy diet } \\
\text { Harmful bacteria } \\
\text { Diabetes } \\
\text { Don't know }\end{array}$ & $\begin{array}{l}2(14.3) \\
6(42.9) \\
1(7.1) \\
1(7.1) \\
4(28.6)\end{array}$ \\
\hline Skin diseases & $\begin{array}{l}\text { Dirty water } \\
\text { Harmful bacteria } \\
\text { Infected blood } \\
\text { Irregular body wash } \\
\text { Basking in the sun regularly }\end{array}$ & $\begin{array}{l}7(50.0) \\
2(14.3) \\
2(14.3) \\
2(14.3) \\
1(7.1)\end{array}$ \\
\hline
\end{tabular}




\begin{tabular}{|c|c|c|c|}
\hline Diseases & $\begin{array}{l}\text { Yes Responses } \\
N(\%)\end{array}$ & How & $\mathbf{N}(\%)$ \\
\hline Diarrhoea & $13(92.9)$ & $\begin{array}{l}\text { Purified water } \\
\text { Tap water } \\
\text { Health consultation } \\
\text { Being hy gienic }\end{array}$ & $\begin{array}{l}6(42.9) \\
3(21.4) \\
2(14.3) \\
2(14.3)\end{array}$ \\
\hline Worms & $13(92.9)$ & $\begin{array}{l}\text { Healthy diet } \\
\text { Health consultation } \\
\text { Being hygienic } \\
\text { Keep pigs away }\end{array}$ & $\begin{array}{l}8(57.1) \\
2(14.3) \\
2(14.3 \\
1(7.1)\end{array}$ \\
\hline Bilharzias & $11(78.6)$ & $\begin{array}{l}\text { Avoid swimming in dams } \\
\text { Not drink water with tadpoles } \\
\text { Use purified water } \\
\text { Use tap water }\end{array}$ & $\begin{array}{l}2(14.3) \\
1(7.1) \\
7(50.0) \\
1(7.1)\end{array}$ \\
\hline Malaria & $9(64.3)$ & $\begin{array}{l}\text { Avoid throwing water on same spot } \\
\text { Opening furrows } \\
\text { Using sprays } \\
\text { Keep surface dry } \\
\text { Keep the area clean } \\
\text { Health consultation }\end{array}$ & $\begin{array}{l}3(21.4) \\
2(14.3) \\
1(7.1) \\
1(7.1) \\
1(7.1) \\
1(7.1)\end{array}$ \\
\hline Eye Infection & $10(71.4)$ & $\begin{array}{l}\text { Healthy diet } \\
\text { Health consultation }\end{array}$ & $\begin{array}{l}5(35.7) \\
5(35.7)\end{array}$ \\
\hline Skin diseases & $13(92.9)$ & $\begin{array}{l}\text { Treatment from health facility } \\
\text { Using purified water } \\
\text { Taking bath regularly } \\
\text { Eating healthy }\end{array}$ & $\begin{array}{l}5(35.7) \\
5(35.7) \\
2(14.3) \\
1(7.1)\end{array}$ \\
\hline
\end{tabular}

and bandages for treating cuts, bites, etc. and insect repellent for mosquitoes, flies, fleas, etc. This view is supported in literature as (DWAF, 1996:14) states that health and hygiene education should be provided to communities in order to: raise awareness of the diseases caused by unhealthy behavior and practices; enable communities to improve their health through correct hygiene practices and increase the demand and willingness to pay for appropriate sanitation facilities (DWAF, 1996: 14). DWAF (1996: 8) further states that often the sanitation challenges in rural areas are associated among others with the lack of access to health and hygiene education (DWAF, 1996: 8). Lack of hygiene education results in an ignorance of the consequences of personal and family hygiene custom and practices (DWAF, 1996: 41). In this regard, DWAF (2002b: 9) has set as its target, the provision of hygiene education to 3 million households by 2010. The enormous backlog of basic water and sanitation services to local communities will not be reduced unless communities themselves

officers $(98.3 \%)$, respectively; health committees $(64.3 \%)$; and water committees $(57.1 \%)$. Communities consulted with various sources when sick $(42.9 \%)$, though most of them $(57.1 \%)$ preferred to go to the hospital/clinic mainly because they received free treatment and had confidence that hospital personnel have knowledge/ experience about diseases (28.6\%). Participants indicated that traditional healers could treat various diseases.

\section{Discussion}

\section{Health of communities}

Communities' health was generally not considered good $(78.6 \%)$ because of limited clean water, lack of money to treat water and unhealthy food. Flies were perceived as a problem in the communities due to unhealthy surroundings (92.9\%). It is assumed that the availability of flies in the communities contributed to diseases that led to poor health. The majority of the communities $(64.3 \%)$ did not have vegetable gardens and therefore did not have vegetables daily $(78.5 \%)$. It is assumed that the lack of vegetables in communities' daily diet contributed to poor nutrition and consequently poor health. The poor health status in the communities is a course of concern because poor health keeps families in a cycle of poverty and lost income, which could otherwise be avoided. The national cost of lost productivity, reduced educational potential and curative health care is substantial (DWAF, 1996: 9; DWAF, $2002 \mathrm{~b}: 1)$. Investing in sanitation can lead to increased life expectancy and savings in health care costs (DWAF, 2001: 9). It can contribute to enhancement of the quality of life through improved general health conditions and well being of the people. All participants were of the opinion that hygiene education is necessary within their communities, even though more than $60 \%$ of the groups indicated that their communities were generally aware of re-hydration mixtures for diarrhoea, medicines and bandages are empowered to undertake their own development. This is not possible if they do not have the skills required which they can only acquire through hygiene education (DWAF, 1994: 20). Although education/training is not cheap, the costs of inadequate sanitation are greater. DWAF (2002a: 48) states that adequate education, among others, is a prerequisite to cost recovery and effective management of service delivery.

\section{Diseases}

The prevalence of diseases in the last 6 months, in descending order, included: skin diseases, worms, eye infections, diarrhoea, bilharzias and malaria and their causes were mainly related to poor sanitation. The results in this regard are in line with the literature that point out that health problems associated with inadequate sanitation are typhoid, bilharzias, malaria, cholera, worms, eye infections, skin diseases and increased risk for bacteria, infections and disease for people with reduced immune systems 


\begin{tabular}{|l|l|}
\hline Community has a: & $\mathbf{N}(\%)$ \\
Health committee & $5(35.7)$ \\
Environmental health officer & $1(7.1)$ \\
Community health worker & $8(57.1)$ \\
Community water committee & $6(42.9)$ \\
Sanitation committee & $1(7.1)$ \\
Services consulted when family member is sick & $\mathbf{N}(\%)$ \\
Traditional Healer & $3(21.4)$ \\
Community Health Care Worker & $1(7.1)$ \\
Self treatment & $2(14.3)$ \\
Clinic / hospital, because & $8(57.1)$ \\
Receive free treatment & $4(28.6)$ \\
Knowledge / experience about diseases & $4(28.6)$ \\
Always available & $1(7.1)$ \\
Have medication & $1(7.1)$ \\
Illnesses treated by Traditional Healers & $\mathbf{N}(\%)$ \\
All & $1(7.1)$ \\
Cancer & $2(14.3)$ \\
Diabetes & $1(7.1)$ \\
High blood pressure & $1(7.1)$ \\
Epilepsy & $1(7.1)$ \\
Diarrhoea & $1(7.1)$ \\
Sores & $1(7.1)$ \\
Cough & $1(7.1)$ \\
Severe headache & $1(7.1)$ \\
Demons / evil spirits & $2(14.3)$ \\
Stroke & $1(7.1)$ \\
Syphilis & $1(7.1)$ \\
\hline
\end{tabular}

due to HIV/AIDS (DWAF, 1996: 39; Tladi et. al. 2002: 17). All diseases suffered, were to a large extent, caused by poor hygiene/sanitation as follows: diarrhoea (100\%); malaria (100\%); skin diseases $(92.9 \%)$; worms $(85.7 \%)$; bilharzias (78.5\%); and eye infections (64.3\%). The prevalence of sanitation-related diseases in rural communities is not surprising in view of the fact sanitation conditions in rural areas are far from satisfactory (Alcock, 1999: 27).

Like in literature, the methods cited by the participants in preventing the abovementioned diseases were related to the improvement of the sanitation conditions (ibid), i.e. they ranged from using purified water, keeping environment clean, being hygienic to having a healthy diet and attending health consultation.

\section{Community Institutional Capacity}

Institutional capacity was generally lacking as more than $50 \%$ of the communities did not have sanitation committees and environmental health officers $(98.3 \%)$, respectively; health committees $(64.3 \%)$; and water committees $(57.1 \%)$. Improved local capacity to manage and maintain completed sanitation facilities is key to sustain sanitation in rural communities (Alaska Native Health Board, 2002: 8). No single agency has the capacity to address all sanitation challenges. The various stakeholders should be brought together to work in collaboration and co-operation to benefit the communities in adopting safe hygienic practices. This implies that other sources that communities consult when they are sick, such as those revealed in the current study (42.9\%), should be acknowledged and used. Collaboration and cooperation of the various stakeholders within communities are critical in addressing hygiene/ sanitation issues (DWAF, 1994: 11 \& DWAF, 1996: 4). UNICEF (1997: 11) states that communities should use existing community organisations rather than creating new ones and that education should be provided to improve both the organisational capacity of the community groups and their problem solving skills. Actions that encourage local leadership, governance and economic development can contribute to enhanced capability in a village to manage, operate and maintain sanitation facilities and other services. Actions that can promote village selfgovernance and leadership include: an acknowledgement that people know their needs and know where to start in meeting these needs; recognize that people can develop solutions to their needs; trust people with resources to directly implement solutions they have identified; and exercise flexibility in programme and project time lines (Alaska Native Health Board, 2002: 4).

\section{Conclusion}

The results of the present study have implications for policy-makers, programme planners, academics and practitioners in the field of water and sanitation in terms of policy and programme formulation, curriculum development, and service delivery. They serve as a knowledge base on which the national, provincial, local governments as well NGOs and the private sector can build strategies for promoting good sanitation practices.

\section{Acknowledgements}

The financing of the project by the Water Research Commission and the contribution of the members of the Steering Committee is acknowledged gratefully.

This study was successful with the cooperation of many individuals and institutions. Sincere thanks to:

The Limakhozu Development Agency team for their dedication, team spirit and commitment to the study.

The villagers in the 14 villages that participated in the study, for their wonderful co-operation in providing the information needed in such an honest and generous way. The group facilitators for their participation in the data collection process. 
The anonymous reviewers are thanked for their useful comments.

\section{References}

ALASKA NATIVE HEALTH BOARD, 2002: Rural sanitation summit. Workshop Summary, April 23 and 24, 2002.

ALCOCK, PG 1999: A water resources and sanitation systems source book with special reference to Kwa-Zulu Natal. Part 6. WRC Report No 384/6/99.

DUNKER, LC 2001: The KAP Tool for hygiene: a manual on knowledge, attitude and practices study for hygiene awareness in the rural areas of South Africa. WRC Report No.TT 144.

DWAF, 1994: White Paper on Water Supply and Sanitation Policy. Pretoria: Government Printers.

DWAF, 1996: National Sanitation Policy. National Sanitation Task Team. Republic of South Africa. Pretoria: Government Printers.

DWAF, 2001: White Paper on Basic Household Sanitation. Pretoria: Government Printers.

DWAF, 2002a: Towards a water services white paper: issues and options discussion paper, April 2002. Republic of South Africa: Government Gazette No. 23377, May 2002.

DWAF, 2002b: Draft White Paper on Water Services, October 2002. Republic of South Africa.

DWAF, 2004: South Africa's Progress Report on Water and Sanitation. United Nations Commission for Sustainable Development, $12^{\text {th }}$ session, 14-30 April 2004.

\section{EASTERN CAPE DEPARTMENT OF SOCIAL DEVELOPMENT 2004: Socio- economic and demographic profile. Bisho: Department of Social Development.}

HEMSON, D 2003: Sustainability of Community Projects in KwaZulu-Natal. Parliamentary Briefing: I September 2003.

HEMSON, D 2004: Beating the backlog: meeting targets and providing free basic services. Position Paper, January 2004. Published by the Human Sciences
Research Council: Integrated Rural and Regional Development.

STEPHEN, DA 2003: Reducing water and sanitation backlogs in rural areas: Umgeni Water's response as an implementing agent within KwaZuluNatal, South Africa. Greener Management International 42. Summer 2003: 47-57.

TLADI, B; BALOYI, T; SCHREIBERKAYA, A; MATHEKGANA, M; MANGOLD, S; DE KLERK, T \& WINDE, F 2002: State of the Environment Report, 2002, North West Province, South Africa.

TUMWINE,JK; THOMSON,J; KATUIKATUA, M;MUJWAHIZI, M; JOHNSTONE, N; \& PORRAS, I 2003: Sanitation and hygiene in urban and rural households in East Africa. Environmental Health Research. 13: 107-115.

UNICEF, 1997: Towards better programming. A Sanitation handbook. Water, Environment and sanitation Technical guideline series no.3. EHP Applied Study No. 5. ID No. UNICEF/ PD/WES/98-3. www.unicef.org 